BMJ Open Ophthalmology

\section{Alpha herpes virus type and viral load in intraocular fluids in patients with acute retinal necrosis}

To cite: von Hofsten J, Bergström T, Zetterberg M. Alpha herpes virus type and viral load in intraocular fluids in patients with acute retinal necrosis. BMJ Open Ophthalmology 2019;4:e000247. doi:10.1136/ bmjophth-2018-000247

Received 3 November 2018 Revised 7 March 2019 Accepted 7 March 2019
Check for updates

(c) Author(s) (or their employer(s)) 2019. Re-use permitted under CC BY-NC. No commercial re-use. See rights and permissions. Published by BMJ.

${ }^{1}$ Department of Ophthalmology, Hallands sjukhus Halmstad, Halmstad, Sweden

${ }^{2}$ Department of Clinical Neuroscience, University of Gothenburg, Mölndal, Sweden ${ }^{3}$ Department of Infectious Disease, Institute of Biomedicine, Sahlgrenska Academy, University of Gothenburg, Institute of Microbiology, Gothenburg, Sweden

Correspondence to Dr Joanna von Hofsten; joanna. vonhofsten@regionhalland.se

\section{ABSTRACT}

Objectives To identify all patients tested positive for herpes viruses in intraocular samples between 2007 and 2016 in South-Western Sweden and evaluate which of these met the criteria of acute retinal necrosis (ARN). To compare viral load in intraocular samples and virus type with clinical outcome.

Method and analysis Retrospective case series. Intraocular samples and serum were analysed with quantitative real-time PCR (qPCR) and presence of antibodies ( $\lg G$ and $\lg M$ ) were detected by ELISA in serum. Results Between 2007 and 2016, 13 patients met the clinical criteria of ARN and were PCR-positive in aqueous or vitreous for herpes simplex virus 1 (HSV1; $n=4)$, herpes simplex virus 2 (HSV2; $n=3$ ) and varicella zoster virus (VZV; $n=6)$. None of the patients tested positive for cytomegalovirus $(n=13)$ or Epstein Barr virus $(n=2)$ met the criteria of ARN. All ARN patients had specific serum IgG and three patients exhibited virus DNA in serum. There was no correlation between high viral load and worse visual outcome. However, higher viral loads were seen in samples taken earlier in the disease process. Median age was higher $(p=0.049)$ in VZV-ARN than for HSV-ARN patients (60.5 and 45.4 years, respectively) with a tendency of worse best corrected visual acuity at presentation (1.62 and $0.79 \log$ MAR, respectively; $p=0.079$ ).

Conclusion ARN is a reactivation of alpha herpes virus and presence of herpes DNA in serum may occur. VZVARN are older than HSV-ARN patients. High viral load does not appear to be a predictor of worse visual outcome, but rather indicates earlier sampling.

\section{INTRODUCTION}

Acute retinal necrosis (ARN) is a serious sight-threatening viral retinitis first described by Urayama and Sasaki. ${ }^{1}$ It is a rare disease affecting one in 2 million people per year. The patients are usually immunocompetent.

Culbertson et al suggested viral aetiology based on findings of suspected herpes-like viruses seen by electron microscopy in all retinal layers of an enucleated eye from an ARN patient. ${ }^{2}$

As laboratory techniques improved it became apparent that ARN was caused by herpes viruses, most commonly varicella zoster virus (VZV) followed by herpes simplex virus 1 and 2 (HSV1 and HSV2). Cytomegalovirus

\section{Key messages}

What is already known about this subject?

ARN is caused by members of the herpes virus family, that is, varicella zoster virus (VZV), Epstein Barr virus (EBV), cytomegalovirus (CMV), herpes simplex virus (HSV) 1 or 2.

- It has been suggested that viral load in intraocular samples may predict a worse visual prognosis.

\section{What are the new findings?}

- We found no correlation between high viral load in intraocular fluids and worse final visual acuity. However, there was a tendency of higher viral load when patients were sampled earlier in the disease process.

In 9 years, in South-Western Sweden, no patient showing positive test for EBV or CMV genome in intraocular samples, exhibited signs of ARN.

- Herpes virus DNA may occur in serum in ARN patients.

\section{How might these results change the focus of research or clinical practice?}

- The information on viral load in intraocular samples should not be used as a prognostic factor, neither to monitor treatment or to predict visual prognosis for individual patients. The timing of sampling is essential as viral load early in the disease process is high and decreases with time.

High doses of acyclovir are used as a standard treatment for ARN. Although being an efficient treatment for infections caused by VZV and HSV1 or HSV2, it is not efficient enough against EBV and CMV. However, if VZV and HSV1 or HSV2 are the only agents responsible for ARN disease we can assume that ARN patients receive the correct treatment.

(CMV) and Epstein Barr virus (EBV) have also been suggested as pathogens. ${ }^{34}$

In 1994, the Executive Committee of the America Uveitis Society stated five diagnostic criteria for ARN: (1) one or more foci of retinal necrosis with discrete borders located in the peripheral retina, (2) rapid progression in the absence of antiviral therapy, (3) circumferential spread, (4) evidence of occlusive arteriolar retinopathy and (5) a 
prominent inflammatory reaction in the vitreous and anterior chamber. ${ }^{5}$

In 2015, Takase et al presented new diagnostic criteria for ARN where one criteria, although not mandatory, demanded PCR positivity of VZV, HSV1 or HSV2 in ocular samples. The new criteria were used in a large validation study on Japanese patients where none of the CMV-positive patients $(n=32)$ had a clinical picture fulfilling the diagnostic criteria of ARN. ${ }^{6}$

Whether ARN is a result of virus reactivation or primary infection is not well established. Cases with ARN in conjunction with chickenpox have been reported in literature. $^{7-10}$

PCR on aqueous or vitreous humour has become the gold standard for diagnosis of ARN. By this method, viral genomes in aqueous and vitreous are easily detected. Quantitative TaqMan real-time PCR (qPCR) provides information on copy number per $\mathrm{ml}$ as well. It has been suggested that viral load in ocular fluids may be related to clinical outcomes in viral uveitis. ${ }^{11-13}$

\section{MATERIALS AND METHODS}

The present study was conducted to evaluate the viral and individual characteristics of all patients treated for ARN in South-Western Sweden between May 2007 and December 2016. The patients were diagnosed at the Department of Ophthalmology at Sahlgrenska University Hospital, Mölndal, or at the Department of Ophthalmology at Halland Hospital in Halmstad. For inclusion, patients had to exhibit positive qPCR tests for any virus from the herpes family in aqueous and/or vitreous samples and meet all criteria of ARN as stated by the American Uveitis Society. Patients were identified by searching the laboratory database on positive aqueous or vitreous samples for HSV1, HSV2, VZV, CMV or EBV. Medical records were reviewed to reveal which of these patients who had suffered from ARN and for information about treatment and clinical course.

All aqueous and vitreous sampling was performed in the surgery department under sterile conditions. All samples were analysed at the Clinical Virology unit of the Microbiology laboratory at Sahlgrenska University Hospital, Gothenburg, Sweden, with qPCR as described previously by Namvar et $a l^{14}$ and Persson et al. ${ }^{15}$ Total nucleic acids were extracted from $100 \mu \mathrm{l}$ of samples by the MagNA Pure LC Total Nucleic Acid Isolation Kit (Roche Diagnostics, Mannheim, Germany). For qPCR, $10 \mu \mathrm{L}$ of extracted nucleic acids were used for each qPCR reaction. For HSV1 and HSV2, the gene for glycoprotein B was targeted in a biplex qPCR, using one type-common and two type-specific primers followed by type-specific probes. Also for VZV, the gB gene was targeted for amplification, and primers and probes were as described previously by Persson et al. ${ }^{15}$ A set of four quantification standards was analysed in duplicate in each run to obtain a plot for verification of qPCR efficiency and quantification of the samples. Similar TaqMan routine diagnostic systems were utilised also for CMV and EBV DNA detection.
During the course of the study, the same laboratory was used and no adjustments were made regarding the qPCR or serology methods. Serum was analysed for immunoglobulin $\mathrm{M}$ and $\mathrm{G}$ for the specific virus, ${ }^{16}$ as well as with qPCR.

Best corrected visual acuity (BCVA) was measured at each visit using a conventional Snellen visual acuity chart. For arithmetic procedures and statistical analysis, decimal acuity was converted to logMAR (logarithm of the minimum angle of resolution) as previously described by Holladay. ${ }^{17}$ For very low BCVA the following logMAR values were assigned; counting fingers 2.6 logMAR, hand movements, $2.9 \log$ MAR, light perception 3.1 logMAR and no light perception $3.4 \log$ MAR. ${ }^{18}$

\section{Patient and public involvement}

Due to the retrospective nature of this study, patients were not invited to plan study design. Patients were not invited to comment interpretations of results nor to contribute to the writing or editing of this manuscript. Included patients will be informed about the results of this study in future contacts with the Ophthalmology Department.

\section{Statistical procedures}

Continuous parameters are presented with mean and $\mathrm{SD}$ or range and significance was analysed with Student's t-test. Categorical parameters are described in proportions and Fisher's exact test was used for significance testing. Data on viral load are presented as copies $/ \mathrm{mL}$ and converted to $\log 10$ for graphical presentation. Correlation analysis was performed to determine associations between viral load and final visual acuity or between days to sampling and viral load, using IBM SPSS Statistics, V.24.

\section{RESULTS}

Thirteen patients (15 eyes) diagnosed between May 2007 and December 2016 met the criteria of ARN and had full medical records. Patient characteristics are shown in table 1.

Of the two patients with bilateral ARN, cases 6 and 13, only the first affected eye was included (which in both cases exhibited the worst visual outcome). These two cases had developed bilateral ARN before adequate treatment was initiated.

Seven patients had been diagnosed by aqueous sampling and six vitreous samples were extracted in conjunction with diagnostic vitrectomy. qPCR analysis identified six cases with VZV, four cases with HSV1 and three cases with HSV2. All patients were tested for multiple viruses; HSV1 and HSV2, VZV and CMV. Four out of 13 eyes were tested for EBV and were negative. qPCR-results are shown in table 2.

All but one sample collected within 17 days after first symptom exhibited high viral loads $\left(\geq 10^{6}\right.$ copies/ $\mathrm{mL})$. Median time from first symptom to sampling in this material was 11 days. Case 3 had his sample taken 
Table 1 Patient characteristics, visual acuity and treatment

\begin{tabular}{|c|c|c|c|c|c|c|c|c|}
\hline Case & Age (years) & Sex & Eye & $\begin{array}{l}\text { BCVA at diagnosis, } \\
\text { decimal (log MAR) }\end{array}$ & $\begin{array}{l}\text { BCVA at last } \\
\text { visit, decimal } \\
\text { (logMAR) }\end{array}$ & Antiviral treatment & $\begin{array}{l}\text { Oral prednisone } \\
\text { days before (-) or } \\
\text { after (+) antivirals }\end{array}$ & $\begin{array}{l}\text { Last follow- } \\
\text { up (months) }\end{array}$ \\
\hline 1 & 63 & $\mathrm{~F}$ & $\mathrm{R}$ & $0.1(1.0)$ & $0.01(2.0)$ & $\begin{array}{l}10 \mathrm{mg} / \mathrm{kg} \times 3 \\
\text { intravenous } \\
\text { acyclovir }\end{array}$ & -48 & 23 \\
\hline 2 & 56 & M & $\mathrm{R}$ & $\mathrm{HM}(2.9)$ & NLP (3.4) & $\begin{array}{l}5 \mathrm{mg} / \mathrm{kg} \times 3 \\
\text { intravenous } \\
\text { acyclovir }^{\star}\end{array}$ & +3 & 10 \\
\hline 3 & 37 & M & $\mathrm{R}$ & $0.1(1.0)$ & $0.4(0.4)$ & $\begin{array}{l}10 \mathrm{mg} / \mathrm{kg} \times 3 \\
\text { intravenous } \\
\text { acyclovir }\end{array}$ & +3 & 11 \\
\hline 4 & 22 & $\mathrm{~F}$ & $\mathrm{~L}$ & 0.05 (1.3) & $\mathrm{HM}(2.3)$ & $\begin{array}{l}10 \mathrm{mg} / \mathrm{kg} \times 3 \\
\text { intravenous } \\
\text { acyclovir }\end{array}$ & +3 & 57 \\
\hline 6 & 71 & M & $\mathrm{L}(\mathrm{Bi})$ & $0.2(0.7)$ & $0.04(2.4)$ & $\begin{array}{l}\text { Oral valacyclovir } \\
500 \mathrm{mg} \times 2\end{array}$ & +11 & 6 \\
\hline 7 & 60 & $\mathrm{~F}$ & $\mathrm{~L}$ & $0.3(0.5)$ & $0.5(0.3)$ & $\begin{array}{l}10 \mathrm{mg} / \mathrm{kg} \times 3 \\
\text { intravenous } \\
\text { acyclovir }\end{array}$ & +3 & 58 \\
\hline 8 & 63 & $\mathrm{~F}$ & $\mathrm{R}$ & $0.3(0.5)$ & $0.07(1.16)$ & $\begin{array}{l}10 \mathrm{mg} / \mathrm{kg} \times 3 \\
\text { intravenous } \\
\text { acyclovir }\end{array}$ & +3 & 21 \\
\hline 9 & 43 & M & $L$ & $0.5(0.3)$ & $0.8(0.1)$ & $\begin{array}{l}10 \mathrm{mg} / \mathrm{kg} \times 3 \\
\text { intravenous } \\
\text { acyclovir }\end{array}$ & -2 & 19 \\
\hline 12 & 68 & $\mathrm{~F}$ & $\mathrm{R}$ & CF (2.6) & $0.1(1.0)$ & $\begin{array}{l}10 \mathrm{mg} / \mathrm{kg} \times 3 \\
\text { intravenous } \\
\text { acyclovir }\end{array}$ & +3 & 5 \\
\hline 13 & 45 & $\mathrm{~F}$ & $\mathrm{R}(\mathrm{Bi})$ & $0.05(1.3)$ & $0.01(2.0)$ & $\begin{array}{l}10 \mathrm{mg} / \mathrm{kg} \times 3 \\
\text { intravenous } \\
\text { acyclovir }\end{array}$ & DM & 4 \\
\hline
\end{tabular}

${ }^{*}$ Reduced dose due to kidney failure.

†Low dose oral acyclovir four days prior to diagnosis.

BCVA, best corrected visual acuity; CF, counting fingers;DM, data missing; F, female; HM, hand movements; L, left; LP, light perception; M, male; NLP, no light perception; $R$, right.

several months after first presentation at a recurrence, yet was correctly treated with antivirals at first presentation.

All patients were treated with intravenous acyclovir 10 $\mathrm{mg} / \mathrm{kg}$ three times per day, except case 6 who was treated orally with valacyclovir $500 \mathrm{mg}$ two times per day. Oral prednisone (60 $\mathrm{mg}$ once a day) was given to all patients, most commonly 3 days after initiation of antiviral therapy and all patients were given topical dexamethasone. All patients were subsequently given oral valacyclovir. No patients were treated with intravitreal injections (ie, foscarnet or ganciclovir). Visual acuity and treatment regimens are presented in table 1.

Medical records of patients tested positive for EBV $(n=2)$ or CMV $(n=13)$ were also reviewed and none of these met the criteria of ARN. Twelve patients were positive for CMV only and one patient for EBV solely. In addition, one patient was positive for both viruses with a higher viral load for CMV and clinical characteristics of typical CMV retinitis. 
Table 2 Viral genome and antibodies against herpes viruses in serum from patients with acute retinal necrosis

\begin{tabular}{|c|c|c|c|c|c|c|c|c|c|c|c|c|c|}
\hline Case & $\begin{array}{l}\text { PCR } \\
\text { ocular }\end{array}$ & $\begin{array}{l}\text { Ocular } \\
\text { fluid }\end{array}$ & $\begin{array}{l}\text { PCR ocular } \\
\text { fluids (copies/ } \\
\mathrm{mL} \text { ) }\end{array}$ & $\begin{array}{l}\text { Symptoms } \\
\text { to sampling } \\
\text { (days) }\end{array}$ & $\begin{array}{l}\text { Treatment } \\
\text { before } \\
\text { sampling } \\
\text { (days) }\end{array}$ & $\begin{array}{l}\text { PCR serum } \\
\text { (copies/mL) }\end{array}$ & $\begin{array}{l}\text { HSV } \\
\text { IgM }\end{array}$ & $\begin{array}{l}\text { VZV } \\
\text { IgM }\end{array}$ & $\begin{array}{l}\text { HSV1 } \\
\text { lgG }\end{array}$ & $\begin{array}{l}\text { HSV2 } \\
\operatorname{lgG}\end{array}$ & $\begin{array}{l}\text { VZV } \\
\lg G\end{array}$ & $\begin{array}{l}\text { CMV } \\
\text { IgG }\end{array}$ & $\begin{array}{l}\text { EBV } \\
\text { IgG }\end{array}$ \\
\hline 1 & VZV & V & $9.4 \times 10^{3}$ & 48 & 0 & - & - & - & + & - & + & + & + \\
\hline 2 & VZV & V & $8.9 \times 10^{8}$ & 5 & 0 & $+(646)$ & - & - & + & + & + & + & + \\
\hline 3 & HSV2 & V & $1.8 \times 10^{2}$ & 270 & $270^{*}$ & NP & NP & NP & + & + & + & + & NP \\
\hline 4 & HSV1 & V & $1.2 \times 10^{7}$ & 6 & 2 & - & - & - & + & - & + & + & + \\
\hline 5 & HSV2 & $A$ & positive & 9 & 0 & - & - & - & + & + & + & + & + \\
\hline 6 & HSV1 & V & $5.8 \times 10^{3}$ & 25 & 0 & - & - & - & + & - & + & - & + \\
\hline 7 & HSV1 & V & $3.6 \times 10^{8}$ & 7 & 2 & + & - & - & + & - & + & + & + \\
\hline 8 & VZV & $A$ & $2.1 \times 10^{7}$ & 12 & 1 & $+(162)$ & - & - & - & + & + & - & + \\
\hline 9 & HSV2 & A & $5.7 \times 10^{3}$ & 8 & 0 & - & - & - & - & + & + & - & + \\
\hline 10 & VZV & $A$ & $1.1 \times 10^{9}$ & 17 & 0 & - & - & - & - & - & + & + & + \\
\hline 11 & VZV & A & $8.4 \times 10^{6}$ & 11 & 7 & - & - & - & - & - & + & + & + \\
\hline 12 & VZV & $A$ & $1.5 \times 10^{6}$ & 12 & 1 & - & - & - & + & + & + & + & + \\
\hline 13 & HSV1 & A & 38 & $>20$ & 1 & - & - & - & + & - & + & + & + \\
\hline
\end{tabular}

Note. +, positive; -, negative.

*Sampling at recurrence.

$\dagger$ first 3 days low dose of acyclovir

A, aqueous;CMV, cytomegalovirus; HSV, herpes simplex virus; NP, not performed;V, vitreous; VZV, varicella zoster virus.

In table 3, a comparison of patients with HSV or VZV ARN is presented. The six cases with VZV had a mean age of 60.5 years (range 55-68). Mean age for the HSV1 patients was 49.5 years (range 22-71). The three HSV2 ARN patients were close in age (mean 40, range 37-43). The age discrepancy between HSV and VZV ARN at diagnosis was statistically significant $(p=0.049)$. VZV ARN presented with lower BCVA compared with HSV ARN at baseline; $\log$ MAR 1.62 compared with $0.79(\mathrm{p}=0.079)$. However, the mean final BCVA was similar regardless of virus type. Two out of four patients with HSV1 ARN (cases 4 and 13) had a history of herpes encephalitis. Case 4 had encephalitis at the age of 15 and case 13 in early childhood. Case 7 with HSV1 ARN had previous recurrent HSV1 iritis.
The presence of viral genome and antibodies against herpetic viruses is shown in table 2. Analyses in aqueous, vitreous fluid and serum are shown. Linear regression showed no correlation between viral load in intraocular fluids and visual outcome (Pearson's $R=0.062, R^{2}=0.004$; $\mathrm{p}=0.857$ ), see figure 1 . In figure 2 , viral load is plotted against days to sampling. There was a trend of lower viral load with more days from diagnosis to sampling (Pearson's $\mathrm{R}=-0.512 ; \mathrm{R}^{2}=0.262 ; \mathrm{p}=0.107$ ). There was no significant difference in viral load between aqueous and vitreous fluid in this material, mean $5.8 \log 10_{10}(\mathrm{SD}$ 2.7) versus $6.5 \log _{10}(\mathrm{SD} 2.5), \mathrm{p}=0.683$. Serum samples were analysed at the time of diagnosis. All ARN patients had IgG antibodies against the causative virus in serum and lacked IgM. Three patients exhibited viral genome

\begin{tabular}{llll}
\hline \multicolumn{4}{l}{ Table 3 Comparison of clinical parameters in relation to virus type } \\
\hline & HSV1+HSV2, $\mathbf{n = 7}$ & VZV, $\mathbf{n = 6}$ & P value $^{*}$ \\
\hline Age, years mean (SD) & $45.4(15.9)$ & $60.5(5.0)$ & $0.049 \dagger$ \\
Sex (F/M), $\mathrm{n}(\%)$ & $3 / 4(43 / 57)$ & $5 / 1(83 / 17)$ & $0.266 \ddagger$ \\
BCVA at diagnosis, log MAR, mean (SD) & $0.79(0.42)$ & $1.62(1.0)$ & $0.074 \dagger$ \\
BCVA at last visit, logMAR, mean (SD) & $1.51(1.22)$ & $1.73(0.97)$ & $0.737 \dagger$ \\
Change in BCVA, mean (SD) & $0.73(1.19)$ & $0.11(0.91)$ & $0.321 \dagger$ \\
Viral load (copies/mL), mean (SD) & $62.0 \times 10^{6}$ & $337 \times 10^{6}$ & $0.256 \dagger$ \\
& $\left(146 \times 10^{6}\right)$ & $\left(514 \times 10^{6}\right)$ & \\
\hline
\end{tabular}

${ }^{*} \mathrm{~A} p$-value of $<0.05$ was considered significant.

†Students' t-test.

$\mp \chi^{2}$-test.

BCVA, best corrected visual acuity; HSV, herpes simplex virus; VZV, varicella zoster virus. 


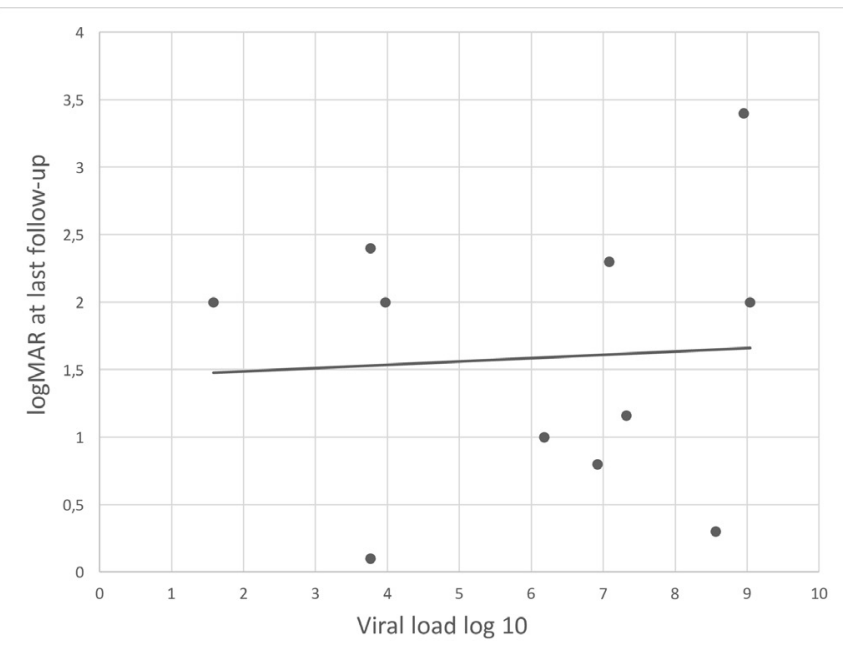

Figure 1 Scatter plot of viral load against visual acuity at last follow-up. Copy number per $\mathrm{mL}$ in ocular fluids is given as log 10 and visual acuity was transformed to logMAR. Pearson's $\mathrm{R}=0.062, \mathrm{R}^{2}=0.004 ; \mathrm{p}=0.857$.

in serum, all of them carrying high amounts of genome in the intraocular sample $\left(\geq 10^{7}\right.$ copies $/ \mathrm{mL}$, table 2$)$.

\section{DISCUSSION}

Of all cases with positive PCR for the herpes virus family in intraocular samples taken between 2007 and 2016, only those with VZV and HSV1 or HSV2 met the criteria for ARN. None of the 12 patients with GMV, one patient with EBV and one patient positive for both viruses, exhibited signs of ARN clinically, which is in keeping with Takase et $a l^{6}{ }^{6}$ Some authors suggest EBV and CMV as possible causes. ${ }^{3} 419$ These viruses usually affect immunocompromised patients and typically have a different clinical picture. Lau et al as well as Hillenkamp et al reported that patients with ARN who tested EBV positive with PCR also were positive for VZV. ${ }^{20} 21$ Low levels of EBV in conjunction with high levels of VZV has also been reported in

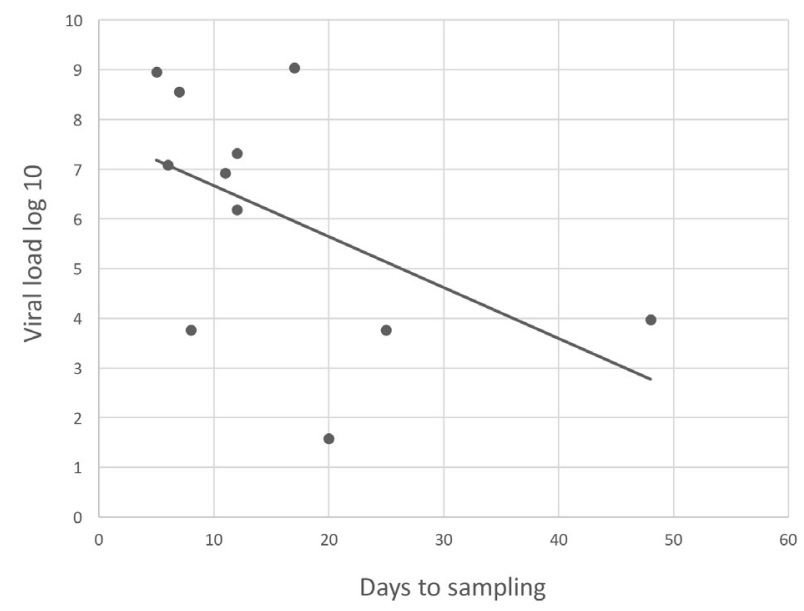

Figure 2 Scatter plot of time to sampling (days) against viral load (log 10). Pearson's $R=-0.512 ; R^{2}=0.262 ; p=0.107$. cerebrospinal fluid in viral CNS disease. ${ }^{15}$ In this material, we did not find positivity for multiple viruses in the same sample as none of patients with ARN had CMV DNA in intraocular fluids and the four samples analysed for EBV DNA were also negative. The hypothesis that ARN is caused exclusively by VZV and HSV1-HSV2 can be explained by the common biological and pathogenic features of these three viruses. All three are members of the alpha herpes virus family with tropism to neuronal tissue during active viral replication and establishment of persistency/latency in sensory ganglia/cranial nerve from where reactivation occurs.

When the patients in this study were grouped after causable virus there was a difference in patient age and history of herpes infection between VZV, HSV1 and HSV2. HSV ARN cases were younger, most notably HSV2 ARN patients. Similar data has previously been described by Ganatra et al who found the median age for onset of ARN in HSV2, HSV1 and VZV to be 20, 47 and 57 years, respectively. ${ }^{19}$ Two out of four HSV1 ARN patients in this study (cases 4 and 13) had a history of herpes encephalitis. These patients were younger than HSV1 ARN patients who did not have a history of CNS infection. Ganatra et al found six out of seven patients with HSV1 ARN to have a history of encephalitis. ${ }^{19}$

In this material, the composition of immunoglobulins in serum in each patient is in keeping with ARN being a reactivation of herpes disease. However, there are case reports of $\mathrm{ARN}$ in conjunction with chickenpox. ${ }^{7-10}$ These cases have in common a delay of 3-4 weeks between chickenpox diagnosis and visual complains.

To our surprise, three serum samples from the time of diagnosis, collected early (5-12 days after onset), also contained viral genome, despite ARN being an infectious process in a small and confined compartment. These patients (two with VZV and one with HSV1 DNA) did not report any general or neurological symptoms and all three had high viral loads (10 log 7-8) of the same virus in intraocular fluids. Since the quantities in the serum samples were close to the detection limit, we speculate that our findings of herpesviral DNA in the blood can be explained by spill-over from the high viral loads in an infected ocular compartment. Nonetheless, one patient (case 10, sampled on day 17) was qPCR-negative in serum despite high intraocular viral load of VZV. Thus, further qPCR analyses of serum samples collected early after onset may reveal if this finding is of additional diagnostic value in patients with ARN.

In this present study, viral load of intraocular samples was compared with the clinical outcome. Linear regression analysis showed no correlation between high viral load and worse visual outcome (figure 1). However, there was a trend of higher levels of herpesviral DNA in patients in whom sampling had been carried out earlier in the course of the disease (Pearson's $\mathrm{R}=-0.512$; $\left.\mathrm{R}^{2}=0.262 ; \mathrm{p}=0.107\right)$, see figure 2 . This could be due to an initial peak of virus particles in ocular tissues preceding a drop as immunoglobulins rise with immunological 
response. Several studies comparing the presence of viral genome or immunoglobulins in aqueous in viral uveitis have shown that PCR is much more likely to be positive from 24 hours to approximately 2 weeks after onset of signs whereas locally produced immunoglobulins rose to significant levels no earlier than 1-2 weeks after onset. ${ }^{22} 23$

Most previous studies on viral load in ARN do not mention time to sampling despite its possible impact. ${ }^{24-26}$ Calvo et al only included patients presenting within a smaller interval from reported symptom onset (5 days) and found a correlation between risk of retinal detachment and higher viral load. ${ }^{12}$ The study by Calvo et al comprised the same number of patients as the present. Our opinion is that one must be aware of the limitations when these patients are seen in a clinical setting. For viral loads to be compared, sampling should be done in the same period of the infectious process, something not easily evaluated simply by asking the patient for duration of symptoms.

Another possible factor affecting viral load is the time of sampling after initiating treatment. In 11 out of 13 patients, treatment was initiated within 2 days prior to sampling. Kinetics of clearance of infection have been studied with repeated aqueous taps during antiviral treatment. ${ }^{24}{ }^{25}$ There is a surprisingly slow decrease of viral genome in aqueous during antiviral treatment, suggesting minor changes if samples are taken within days after initiation of treatment compared with prior to initiation.

In addition to the factors mentioned above, the virus type might have an impact on viral load (table 3). In the group of VZV ARN, ocular samples carried a higher amount of viral genome compared with HSV ARN and had worse visual acuity at baseline. These differences were not significant however, maybe due to small sample size. HSV1 and HSV2 patients tended to have better BCVA at presentation and deteriorated during treatment. An initial worse visual acuity and higher risk for retinal detachment in VZV ARN compared with HSV ARN have been described previously. ${ }^{27}$

Investigators have compared viral load in cerebrospinal fluid and prognosis in herpes encephalitis. Most of them demonstrate no correlation between viral load and prognosis/mortality. ${ }^{28-30}$

A limitation of the current study is the small sample size. Because of ARN being a rare disorder, most case series are small. Moreover, Sweden is a sparsely populated country making rare diseases seldom encountered.

\section{CONCLUSION}

ARN is caused by a reactivation of alpha herpes viruses (VZV, HSV1 and HSV2) as seen in this cohort of Scandinavian patients. Patients with ARN caused by VZV are older at presentation and tend to have higher viral load and lower initial BCVA compared with ARN caused by HSV1 and HSV2. We found no correlation between viral load and visual prognosis. Care should be taken when interpreting viral load as a prognostic marker. Many factors contribute to viral load, most importantly time from onset of symptoms to sampling.

Serum samples may be qPCR positive for the responsible herpes virus early after onset.

Contributors JvH, TB and MZ planned the study. TB contributed with analysis and interpretation of data. JvH conducted the study, wrote and submitted the manuscript. TB and MZ revised the manuscript and gave final approval.

Funding This work has been supported by grants from the Swedish government ("Agreement concerning research and education of doctors"; ALF-GBG-441721), Vetenskapliga rådet, HALLAND-724231, Region Halland, HALLAND-685521, D\&B Dahlins stiftelse.

Competing interests None declared.

Patient consent for publication Informed patient consent was not required according to the Regional Ethics Committee in Gothenburg, as this was a retrospective study.

Ethics approval The study was approved by the Regional Ethics Committee in Gothenburg and the tenets of the Declaration of Helsinki were followed.

Provenance and peer review Not commissioned; externally peer reviewed.

Open access This is an open access article distributed in accordance with the Creative Commons Attribution Non Commercial (CC BY-NC 4.0) license, which permits others to distribute, remix, adapt, build upon this work non-commercially, and license their derivative works on different terms, provided the original work is properly cited, appropriate credit is given, any changes made indicated, and the use is non-commercial. See: http://creativecommons.org/licenses/by-nc/4.0/.

\section{REFERENCES}

1. Urayama AYN, Sasaki T. Unilateral acute uveitis with periarteritis and detachment. Jpn J Clin Ophthalmol 1971;25:607-19.

2. Culbertson WW, Blumenkranz MS, Haines $\mathrm{H}$, et al. The acute retinal necrosis syndrome. Part 2: histopathology and etiology. Ophthalmology 1982;89:1317-25.

3. Schaal S, Kagan A, Wang Y, et al. Acute retinal necrosis associated with Epstein-Barr virus: immunohistopathologic confirmation. JAMA ophthalmology 2014;132:881-2.

4. Yeh S, Suhler EB, Smith JR, et al. Combination systemic and intravitreal antiviral therapy in the management of acute retinal necrosis syndrome. Ophthalmic Surg Lasers Imaging Retina 2014:45:399-407.

5. Holland GN. Standard diagnostic criteria for the acute retinal necrosis syndrome. Executive Committee of the American uveitis Society. Am J Ophthalmol 1994;117:663-7.

6. Takase H, Okada AA, Goto $\mathrm{H}$, et al. Development and validation of new diagnostic criteria for acute retinal necrosis. Jpn J Ophthalmol 2015;59:14-20.

7. Gargouri S, Khochtali S, Zina S, et al. Ocular involvement associated with varicella in adults. J Ophthal Inflamm Infect 2016;6.

8. Gupta R, Tyagi M, Balakrishnan D, et al. Acute retinal necrosis (Arn) following chickenpox in a patient of Vogt-Koyanagi-Harada (VKH) syndrome using immunosuppressants. BMJ Case Rep 2018;11.

9. Shin YU, Kim J, Hong EH, et al. Varicella zoster virus-associated necrotizing retinitis after chickenpox in a 10-year-old female: a case report. Pediatr Infect Dis J 2017;36:1008-11.

10. Yu J, Ashworth J, Hughes S, et al. Varicella-zoster virus necrotising retinitis, retinal vasculitis and panuveitis following uncomplicated chickenpox in an immunocompetent child. BMJ Case Reports 2018;91.

11. Abe T, Sato M, Tamai M. Correlation of varicella-zoster virus copies and final visual acuities of acute retinal necrosis syndrome. Graefes Arch Clin Exp Ophthalmol 1998;236:747-52.

12. Calvo CM, Khan MA, Mehta S, et al. Correlation of clinical outcomes with quantitative polymerase chain reaction DNA copy number in patients with acute retinal necrosis. Ocul Immunol Inflamm 2017;25:246-52.

13. Kido S, Sugita S, Horie S, et al. Association of varicella zoster virus load in the aqueous humor with clinical manifestations of anterior uveitis in herpes zoster ophthalmicus and zoster sine herpete. $\mathrm{Br} J$ Ophthalmol 2008;92:505-8

14. Namvar L, Olofsson S, Bergström T, et al. Detection and typing of herpes simplex virus (HSV) in mucocutaneous samples by TaqMan PCR targeting a gB segment homologous for HSV types 1 and 2. $J$ Clin Microbiol 2005;43:2058-64. 
15. Persson A, Bergström T, Lindh M, et al. Varicella-zoster virus CNS disease--viral load, clinical manifestations and sequels. J Clin Virol 2009;46:249-53.

16. Grahn A, Studahl M, Nilsson S, et al. Varicella-zoster virus (VZV) glycoprotein $E$ is a serological antigen for detection of intrathecal antibodies to VZV in central nervous system infections, without cross-reaction to herpes simplex virus 1. Clin Vaccine Immunol 2011;18:1336-42.

17. Holladay JT. Proper method for calculating average visual acuity. $J$ Refract Surg 1997;13:388-91.

18. Johnson LN, Guy ME, Krohel GB, et al. Levodopa may improve vision loss in recent-onset, nonarteritic anterior ischemic optic neuropathy. Ophthalmology 2000;107:521-6.

19. Ganatra JB, Chandler D, Santos C, et al. Viral causes of the acute retinal necrosis syndrome. Am J Ophthalmol 2000;129:166-72.

20. Hillenkamp J, Nölle B, Bruns C, et al. Acute retinal necrosis: clinical features, early vitrectomy, and outcomes. Ophthalmology 2009;116:1971-5.

21. Lau $\mathrm{CH}$, Missotten $\mathrm{T}$, Salzmann J, et al. Acute retinal necrosis features, management, and outcomes. Ophthalmology 2007;114:756-62.

22. de Boer JH, Verhagen $\mathrm{C}$, Bruinenberg $\mathrm{M}$, et al. Serologic and polymerase chain reaction analysis of intraocular fluids in the diagnosis of infectious uveitis. Am J Ophthalmol 1996;121:650-8.

23. De Groot-Mijnes JDF, Rothova A, Van Loon AM, et al. Polymerase chain reaction and Goldmann-Witmer coefficient analysis are complimentary for the diagnosis of infectious uveitis. Am J Ophthalmol 2006;141:313-8.

24. Asano S, Yoshikawa T, Kimura H, et al. Monitoring herpesviruses DNA in three cases of acute retinal necrosis by real-time PCR. $J$ Clin Virol 2004;29:207-10.

25. Bernheim D, Germi R, Labetoulle M, et al. Time profile of viral DNA in aqueous humor samples of patients treated for varicella-zoster virus acute retinal necrosis by use of quantitative real-time PCR. J Clin Microbiol 2013;51:2160-6.

26. Cottet L, Kaiser L, Hirsch $\mathrm{HH}$, et al. HSV2 acute retinal necrosis: diagnosis and monitoring with quantitative polymerase chain reaction. Int Ophthalmol 2009;29:199-201.

27. Wong R, Pavesio CE, Laidlaw DA, et al. Acute retinal necrosis: the effects of intravitreal foscarnet and virus type on outcome. Ophthalmology 2010;117:556-60.

28. Hjalmarsson A, Granath F, Forsgren M, et al. Prognostic value of intrathecal antibody production and DNA viral load in cerebrospinal fluid of patients with herpes simplex encephalitis. J Neurol 2009;256:1243-51.

29. Poissy J, Champenois K, Dewilde A, et al. Impact of herpes simplex virus load and red blood cells in cerebrospinal fluid upon herpes simplex meningo-encephalitis outcome. BMC Infect Dis 2012;12.

30. Růzek D, Piskunova N, Zampachová E. High variability in viral load in cerebrospinal fluid from patients with herpes simplex and varicellazoster infections of the central nervous system. Clin Microbiol Infect 2007;13:1217-9. 